\title{
軽量高保水性外装資材を用いた 建物遮熱性の実証的研究
}

\author{
山田 宏之 1 ・田中 明則 2 - 奥田 芳雄 ${ }^{3}$ \\ 1 和歌山大学助教授 システム工学部環境システム学科（テ640-8510 和歌山県和歌山市栄谷930) \\ E-mail: hyamada@sys.wakayama-u.ac.jp \\ 2 株式会社森生テク) 代表取締役（干540-0012大阪市中央区谷町2-7-5） \\ E-mail:sinsei_tecno@yahoo.co.jp \\ 3 有限会社エコプロ 代表取締役（† $661-0033$ 兵庫県尼崎市武庫之荘3-4-1-112） \\ E-mail: ecopro@hcc1.bai.ne.jp
}

\begin{abstract}
建築物屋上や壁面に設置することができる軽量な保水板を用いて，実物のコンテナハウス内の熱環境改 善効果の実測と，それに伴う冷房負荷の低減効果の検証を行った. その結果，建物屋根面の温度を24.3 $27.6^{\circ} \mathrm{C}$, 天井面温度を $6.2 \sim 10.4^{\circ} \mathrm{C}$, 室内の平均輻射温度を $1.7 \sim 6.1^{\circ} \mathrm{C}$ 低減することが分かった。 また，屋根 面のみを被覆した場合で $29.3 \%$, 屋根面と壁面のうち2面を被覆した場合で $46.2 \%$ 空調電力量の削減効果 が得られ，空調排熱の削減にも有効であることが判明した。
\end{abstract}

Key Words : temperature, heat insulation, heat island, PMV, water contain board

\section{1. はじめに}

東京都や大阪府など大都市を中心に, さまざまなヒ一 トアイランド対策が取られるようになってきている1). そのような対策の一つに道路面の透水化，保水化があげ られるが，現在までに多数の舗装資材が開発され，その 効果が解析されてきている2３）．建築物においては, 屋上緑化や高反射塗装等の研究・開発が進められている が, 保水性資材を建物表面に設置するような事例は数少 ない。

現在作られている透水性, 保水性のブロックは歩道面 などの舗装用に開発されているものがほとんどであり， 耐久性には優れるが，建築物屋上や壁面に設置するには 重過ぎる上に，適切な固定方法に乏しいという問題点が あげられる。

そこで，建築物表面に設置するのに適する軽量性と加 工性の良さ，また高い含水率を同時に実現するための新 しい保水板の開発を行った. 本研究は, この新しく開発 された保水板を用いて, 実物のコンテナハウス内の熱環 境改善効果の実測と, それに伴う冷房負荷の低減効果の 検証を行い, ヒートアイランド対策, 室内暑熱環境改善 資材としての有効性を検証することを目的とした。

\section{2. 研究方法}

実験は，同一規格のコンテナハウスを2棟設置し，一 方の屋根面および壁面に保水板を固定して，それぞれの 建物内温度, 天井面熱流, 室内平均輻射温度, 体感温度 等の比較を行った.

実験期間は4期に分け，1週目は屋上のみを保水板で被 覆して密閉・無空調状態での室内熱環境の測定, 2週目 は1週目と同じ設定の建物を使って，同一設定温度で空 調を行った場合の室内熱環境と消費電力量の測定, 3 週 目は, 屋上に加えて壁面のうち2面を保水板で被覆し, 密閉・無空調状態での室内熱環境の測定，4週目は3週目 と同じ設定の建物を使って, 同一設定温度で空調を行っ た場合の室内熱環境と消費電力量の測定を行った.

\section{（1）保水板の概要}

実験に使用した保水板は（株）森生テクノが開発した ものであり (特許申請中)，数種類の鉱物性の原料とモ ルタルで製造されている. 乾燥時の比重は約 $0.6 \mathrm{~g} / \mathrm{cm}^{3}$, 最大体積含水率は約 $60 \%$ の, 軽量で保水性の高い資材で ある. また, 手動のノコギリで簡単に切断でき, ドリル での穴開けも容易であるなど，建築物表面への取り付け の際の施工性を向上させている.

実験に用いた保水板は $300 \mathrm{~mm} \times 300 \mathrm{~mm} \times 25 \mathrm{~mm}$ で作成 した. 予備的な実験の結果, この $25 \mathrm{~mm}$ 厚の板を水分飽 
和させた状態で, 夏季の晴天時に 2 日間以上冷却能力が 持続することを確認した。

この保水板は白色で，敷き並べた状態で日射計を用い て測定した平均的な表面反射率は $51.4 \%$ あるる.

\section{（2）実験装置}

比較実験に使用したのは，内寸 $1800 \mathrm{~mm} \times 3600 \mathrm{~mm} \times$ 2300mmのコンテナハウス (スーパーハウス) である. 愛知県名古屋市内の住宅敷地に2棟を並べて設置した. それぞれのコンテナハウスには同一規格のエアコンと電 力計を設置し, 実際の使用状況を想定して, 北側空は内 側から目張りし，南側空の外側にはヨシズを立て掛けた。

一方の建物の屋根面全面に保水板を敷き並べて処理区 とし（写真-1），もう一方を対照区とした実験を最初の 2週間行った. その後, 処理区の南面と西面の2面の壁面 全面（ただし空部分を除く）に保水板を追加設置して後 半2週間の実験を行った.

建物外では日射量と気温の測定を行った。それぞれの 建物では, 屋根面温度, 天井面温度, 天井面熱流, 床面 上 $1.5 \mathrm{~m}$ の気温, 床面上 $1.1 \mathrm{~m}$ の気温, 床面上 $1.1 \mathrm{~m}$ の相 対湿度, 床面上 $1.1 \mathrm{~m}$ の黒球湿度, 床面上 $1.1 \mathrm{~m}$ の風速の 測定を行った. 使用した計測器は表-1にまとめた.

また，これらの測定結果から床面上1.1mのPMVと平 均輻射温度を求めた. PMV (Predicted Mean Vote : 予測平 均申告）とは，温熱感に関する快適性を表す指数であり， 1970 年にデンマーク工科大学のFangerにより発表された 4). 現在では, 中庸な温熱環境を表す指標としてISOに 規定されている世界標準指標である ${ }^{5)}$. PMV 值を計算 することにより, 温度環境に関する 6 要素 (空気温度, 平均輻射温度, 気流, 湿度, 着衣量, 代謝量) の全てを 勘案した温熱感を求めることができる.

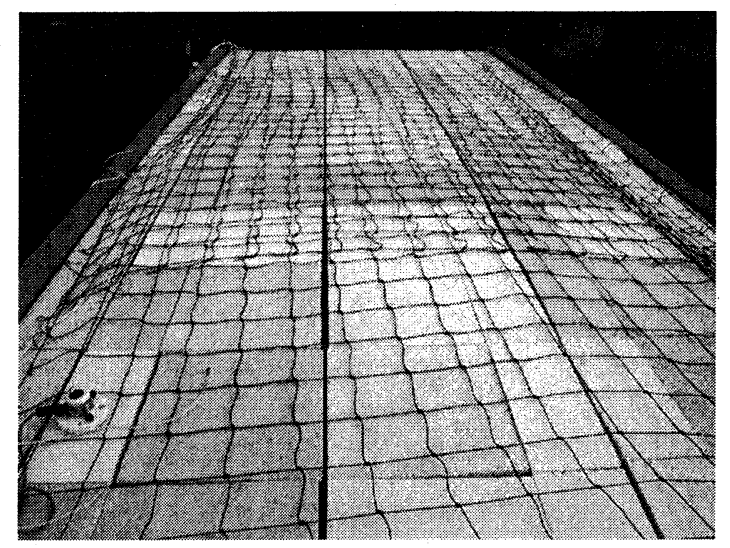

写真-1 コンテナハウス屋根面への保水板の設置状況
表-1 測定機器一覧

\begin{tabular}{|c|c|}
\hline 測定項目 & 測定機器 \\
\hline 日射量 & 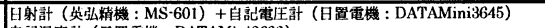 \\
\hline 外気温 & 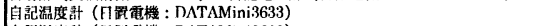 \\
\hline 屋根面温度 & 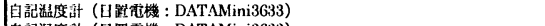 \\
\hline 天井面温度 & 自記温度計 (日置雨機 : DATAMini3633) \\
\hline 天㭌面整流 & 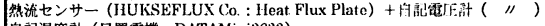 \\
\hline 休上 $1.5 \mathrm{~m}$ 空温 & 自記温度計（日䈯電機 : DATAMini3633） \\
\hline 休上 $1.1 \mathrm{~m}$ 空温 & PMV計測装贯（京都電子工業 : AM-101） \\
\hline 床上 $1.1 \mathrm{~m}$ 相対湿度 & PMV計测装置（京都電子工業：AM-101） \\
\hline 床上 $1.1 \mathrm{mMRT}$ & PMV 辣测装置（京都電子工業：AM-101） \\
\hline 速上1.1m風速 & PMV竍测装置（亨都電子工業：AM-101） \\
\hline
\end{tabular}

なお, 本論では空気温度, 平均輻射温度, 気流, 湿度 は実測值を用いたが，着衣量は0.5 clo（夏服を想定）， 代謝量は 1.0 met（座ってくつろいでいる状態）と定数化 して計算している.

PMV值は-3〜+3 までの数值で示され，+3は「暑い」， +2 は「暖かい」を示す. $\mathrm{PMV}=0$ で, 人間内部の熱生産 と環境との熱損失が等しく熱的平衡状態となり, 暑くも 寒くもない温冷感となる.

\section{（3）実験期間および方法}

実験は2005年8月15日から9月14日まで行われた。8月 15日から28日までは屋根面のみに保水板を設置した。そ のうち，8月15日から21日までは密閉して無空調状態で 測定を行った。 22 日から 28 日までは設定温度 $28^{\circ} \mathrm{Cで}$ 連続 空調を行いながら測定し，消費電力量を記録した. 8月 29日から9月14日までは，屋根面および南向き壁面，西 向き壁面に保水板を設置した.そのうち，8月29日から9 月4日までは密閉して無空調状態で測定を行った.4日か ら14日までは設定温度 $28^{\circ} \mathrm{C} て ゙$ 連続空調を行いながら測定 し，消費電力量を記録した。

実験期間中は 2 日に1度の割合で保水板に散水し，十分 な水分を与えた. 散水は, 保水板下部からの水の流出が 認められるまで行った。

なお，本実験では，無空調状態では室温が40 $\mathrm{C}$ 以上に 上昇し，居住環境として見た場合には非現実的な熱環境 となるが, 工事現場のコンテナハウスは無人時には無空 調で密閉されており，このような状態は現実に頻繁に起 こっていること, また, 密閉時の高温化は室内備品の劣 化促進や，再空調時の負荷増大などの問題を引き起こす 原因になると考え，あえてこのような設定を行ったもの である

\section{3. 結果および考察}

\section{(1) 気象条件}

測定期間中は台風の通過などもあって, 天候は不安定 であった.そこで4期の測定期間中から，それぞれ最も 天候条件が安定していた日を抽出し，主にその1日分の データの比較を行うこととした。抽出したのはそれぞれ， 2005年8月19日，27日，9月3日，13日である。 


\section{（2）屋根のみ被覆·無空調時の比較}

最も天候が安定していた8月19日の日射量変化を図-1 に示す．8月19日は雲の通過が頻繁にあったが，日積算 日射量は $18.8 \mathrm{MJ} / \mathrm{m}^{2}$ と比較的大きな值を示した．温度測 定の結果を図-2に示す. 対照区の屋根面は最高で $59.9^{\circ} \mathrm{C}$ に達したが, 保水板表面はおおむね $35^{\circ} \mathrm{C}$ 程度であり, 最

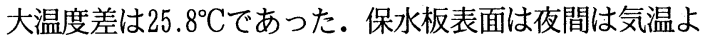
りも低温となり，最大で気温よりも $2.9^{\circ} \mathrm{C}$ 低下した。日 中は気温よりも若干高くなるが, 最大でも $5.3^{\circ} \mathrm{C}$ 程度し か高くならない. 表面温度の低減効果は非常に高く, 外 気への顕熱量を減らすという点でヒートアイランド対策 上，有効であると考えられる.

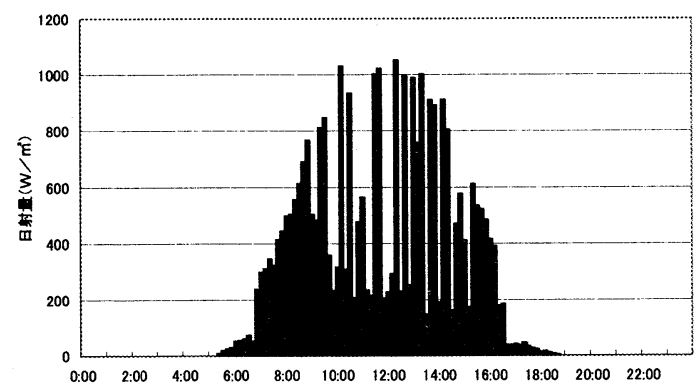

図-1２005年8月19日の日射量変化

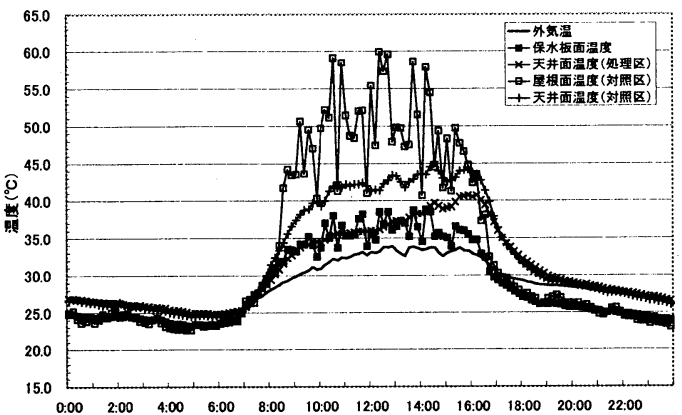

図-2 2005年8月19日の各部温度変化

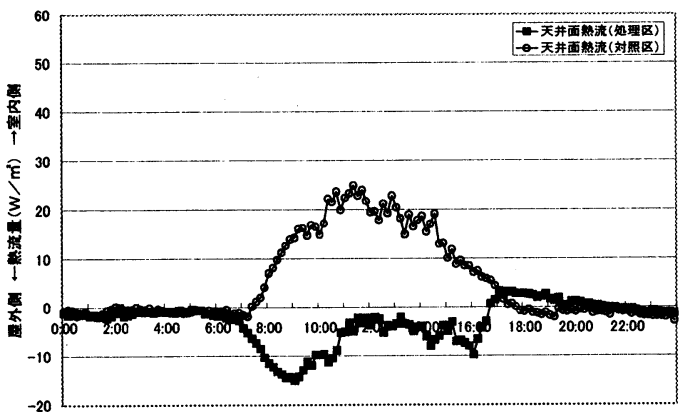

図-3２005年8月19日の天井面熱流変化
室内側について見ると, 天井面温度では最大 $6.9^{\circ} \mathrm{C}$, 室温では最大 $2.5^{\circ} \mathrm{C}$ 差となった. PMVは処理区，対 照区ともに日中は常に3.0（暑い）を示し，大きな差異 は認められなかったが，平均輻射温度は，日中は処理区 の方が低く，最大で $1.7^{\circ} \mathrm{C}$ 差となった.

天井面熱流の測定結果を図-3に示す．対照区では，日 中は最大 $24.9 \mathrm{~W} / \mathrm{m}^{2}$ の熱が天井面から屋内側に流入し， 夜間は僅かに放熱となっている，処理区では，日中は最 大で $15.1 \mathrm{~W} / \mathrm{m}^{2}$ の熱が天井面から外部に放出されており， 熱の出入り関係は全く逆となっている. 日積算値を求め ると, 対照区では $454.6 \mathrm{~kJ} / \mathrm{m}^{2}$ の建物内への吸熱, 保水板 を設置した処理区の場合は $261.7 \mathrm{~kJ} / \mathrm{m}^{2}$ の放熱となってい る.これは保水板の設置により屋根面が低温になってい るのに対して，建物側面等からの流入熱等の影響により 室温が天井面よりも高温になるため生じる現象であり, 屋根面冷却の効果を端的に表す結果であると考えられる.

\section{（3）屋根のみ被覆·空調時の比較}

最も天候が安定していた8月27日の日射量変化を図-4 に示す。8月27日はほぼ1日中快晴となり，理論值に近い 日射量変化となった。日積算日射量は $24.4 \mathrm{MJ} / \mathrm{m}^{2}$ と大き な值を示した.

温度測定の結果を図-5に示す. 屋根面で最大 $27.5^{\circ} \mathrm{C}$, 天井面で最大 $7.1^{\circ} \mathrm{C}$ 差が生じた. 空調設定値はともに $28^{\circ} \mathrm{C}$ であるが，室温に若干の差が生じていた。これは空

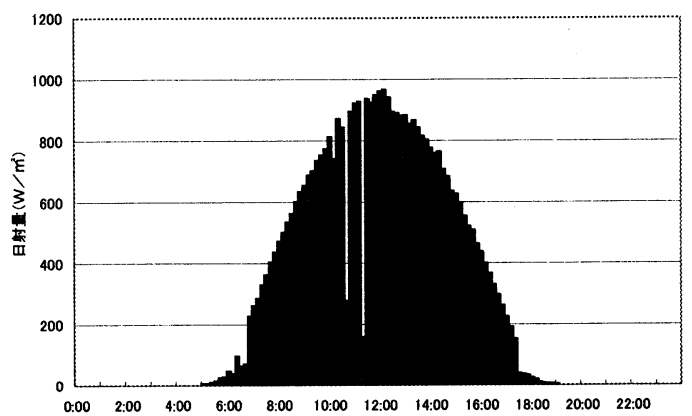

図-4 2005年8月27日の日射量変化

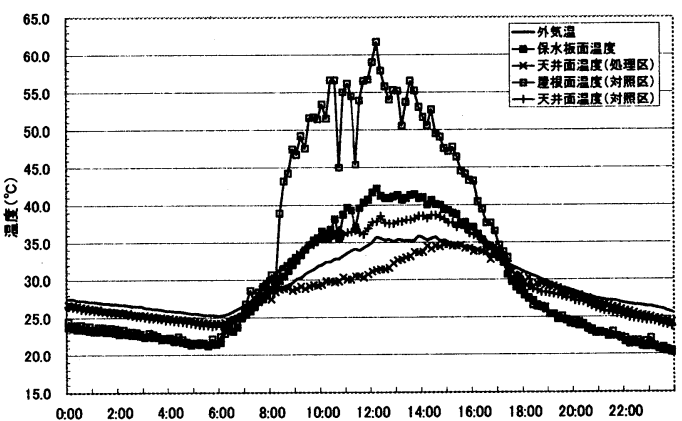

图-5 2005年8月27日の各部温度変化 
調機が空気取り入れ口の気温で温度制御を行っているた めであり, 別途設置した天井面付近の温度センサーによ って, 空気取り入れ口付近の気温は等しい事を確認して いる.

PMVの測定結果を図-6に示す. 空調が作動していな い夜間においては処理区の方がPMVは高く，これは室 温等の測定結果と同じ傾向である. 日中は処理区が $\mathrm{PM}$ $\mathrm{V}=1.0 \sim 1.5$ 程度であるのに対して，対照区は1.0付近 から正午にかけて徐々に低下し， -0.5 程度にまで低下し， その後再び1.0程度に戻った. 図-7の室温, 平均輻射温 度の変化を見ると, 対照区の室温が正午にかけて徐々に 低下し， $25^{\circ} \mathrm{C}$ 程度まで下がっていることがわかる．これ は前述したように, 空調機の空気取り入れ口が天井付近 に位置し, 空調機は吸気気温で出力コントロールを行う ため, 天井面付近ではともに気温 $28^{\circ} \mathrm{Cに}$ 保たれているも のの，PMVを測定した床面上 $1.1 \mathrm{~m}$ といった低い位置 では過剩冷房状態となってしまっているためと考えられ る. 室温と平均輻射温度との差を見ると，対照区で平均 輻射温度が顕著に高いことが分かる．これも天井面の高 温化が影響しているものと考えられる.

天井面熱流の測定結果を図-8に示す. 対照区では，日 中は最大 $53.9 \mathrm{~W} / \mathrm{m}^{2}$ の熱が天井面から屋内側に流入し, 保水板設置区との差が非常に大きく現れている. 空調の 影響で天井面温度が屋根面温度よりも低いため，保水板

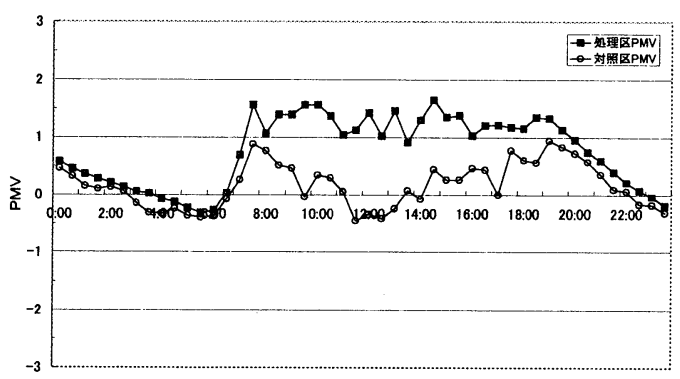

図-6 2005年8月27日のPMV比較

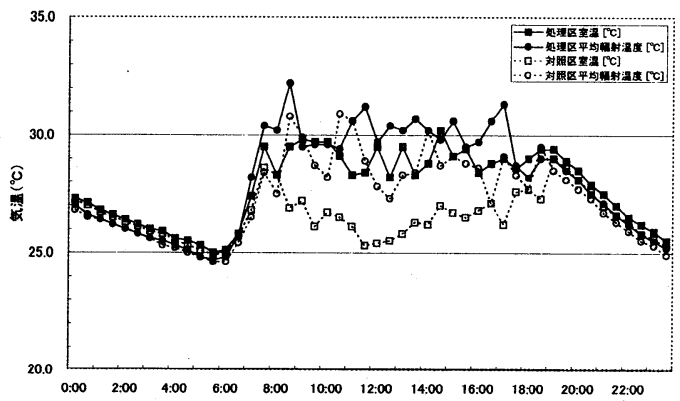

図-7 2005年8月27日の室温, 平均輻射温度比較

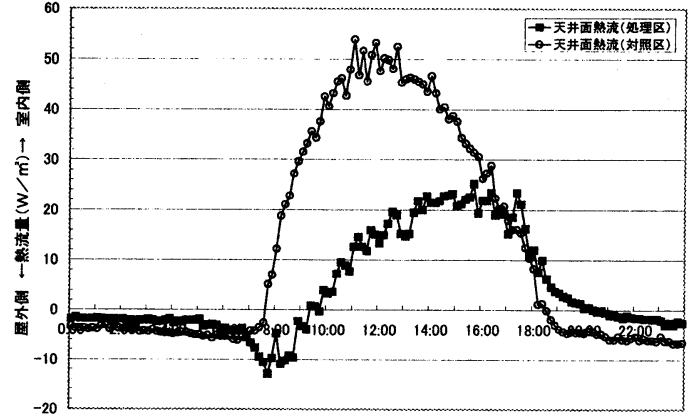

図-8２005年8月27日の天井面熱流変化

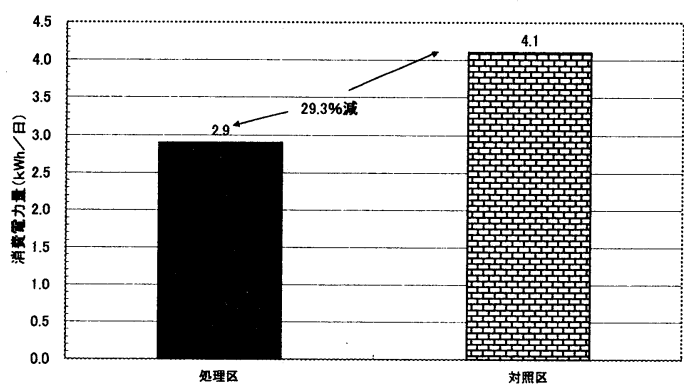

図-92005年8月27日の消費電力量比較

被覆区も室内側への放熱となるが，最大熱流は23.2W/ mであり，天井面からの熱流は対照区の半分以下である. 日積算熱量は対照区 $1086.6 \mathrm{~kJ} / \mathrm{m}^{2}$, 保水板設置区 $384.5 \mathrm{~kJ} /$ $\mathrm{m}^{2}$ で，保水板設置により $64.6 \%$ 減となった.

また，空調による1日の電力消費量は図-9のように対 照区で4.1kWh，処理区で2.9kWhとなり，電力消費量は 29.3\%減となった. なお, PMV測定を行った床面1.1 $\mathrm{m}$ 付近では対照区側が過剩冷房状態となっているため, これが実際に使用している建物での省エネルギ一効果を 直接的に表すことにはならない.

次に全測定期間中，最も天候条件が安定していた8月 27日のデータを用い，処理区と対照区の温度差と日射量 との関連性について解析を行った。8月27日の測定結果 のうち, 日射が雲に遮られた2デ一夕を除いて，屋根面 温度と気温との差（屋根面温度一気温）と日射量との関 連について回帰分析を行った結果が図-10である.それ ぞれ決定係数は 0.95 以上となり, 日射量との相関は強い。 回帰式から, 保水板表面温度が気温と等しくなり顕熱量 ゼロとなるのは日射量 $360.4 \mathrm{~W} / \mathrm{m}^{2}$, 無処理の鉄板面の場 合は $152.1 \mathrm{~W} / \mathrm{m}^{2}$ と計算された. 日射量 $100 \mathrm{~W} / \mathrm{m}^{2}$ 当たりの 温度上昇量は，保水板で $1.1^{\circ} \mathrm{C}$, 鉄板面で $2.8^{\circ} \mathrm{C}$ となっ。

同様に, 処理区と対照区の屋根面温度, 天井面温度と の差（対照区一処理区）と日射量との関連を調べた結果 が図-11である.この場合でも決定係数は 0.95 以上とな 
り, 日射量との相関が強い.日射量 $900 \mathrm{~W} / \mathrm{m}^{2}$ 時には, 屋 根面で $21.9^{\circ} \mathrm{C}$, 天井面でも $5.7^{\circ} \mathrm{C}$ 温度差が生じる計算 となり，これが保水板の蒸発潜熱と反射率の増加によっ てもたらされた効果と考えられる. なお，実測上の鉄板 面の反射率は $39.1 \% て ゙ ，$ 保水板よりも $10 \%$ 以上少ない。

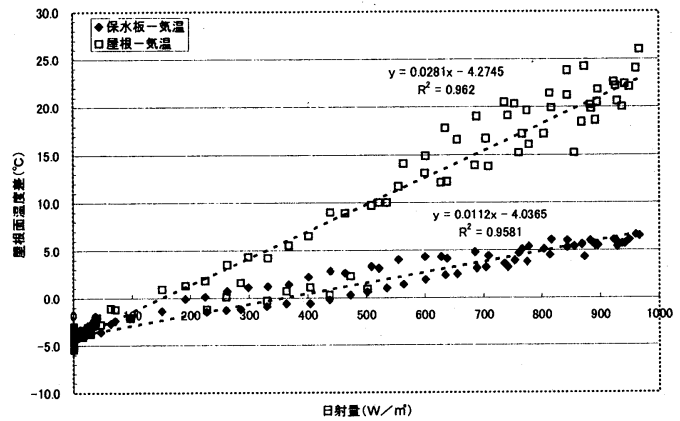

図-10 屋根面温度と日射量との関係

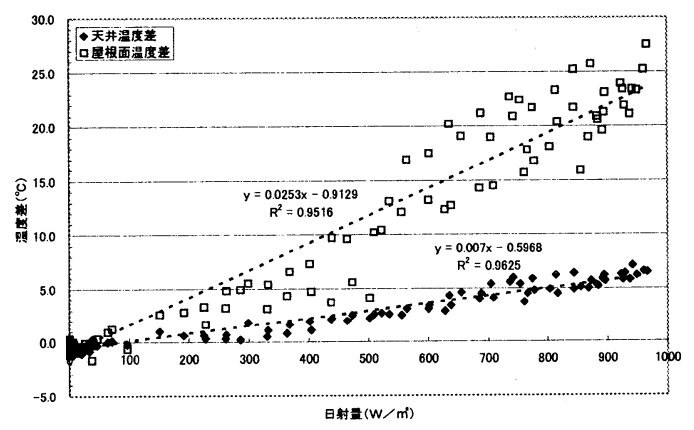

図-11 処理区・対照区間の屋根面と天井面温度の比較

\section{（4）屋根と壁を被覆・無空調時の比較}

最も天候が安定していた 9 月3日の日射量変化を図-12 に示す。9月3日はほぼ1日中快晴となり，日積算日射量

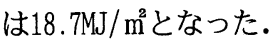

温度の測定結果を図-13に示す. 屋根面で最大 $27.6^{\circ} \mathrm{C}$, 天井面で最大 $10.4^{\circ} \mathrm{C}$ 差が生じた。

PMVの測定結果を図-14に示す.日中はともに3.0に 達したが，処理区の方が1.5時間遅れて3.0に達し，夕方 も早く3.0以下になった. 平均輻射温度には大きな差が 生じ，最大 $6.1^{\circ} \mathrm{C}$ 差となった.

天井面熱流の測定結果を図-15に示す．対照区では， 日中は最大 $29.3 \mathrm{~W} / \mathrm{m}^{2}$ の熱が天井面から屋内側に流入し， 夜間は $5.0 \mathrm{~W} / \mathrm{m}^{2}$ 程度の放熱となっている. 処理区では, 日中は最大 $7.2 \mathrm{~W} / \mathrm{m}^{2}$ の熱が天井面から外部に放出されて おり，8月19日と同様に熱の出入り関係は逆となる.1日 分を積算すると, 対照区は $366.3 \mathrm{~kJ} / \mathrm{m}^{2}$ の吸熱, 処理区 は-236.1kJ/ $\mathrm{m}^{2}$ と放熱になっている. 壁面2面を保水板で 被覆した場合でも，室内に侵入した熱を，天井面から外
部に放出していることになる.

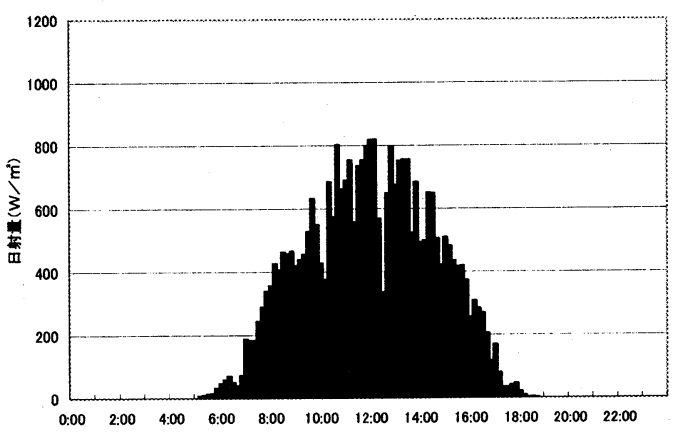

図-12 2005年9月3日の日射量変化

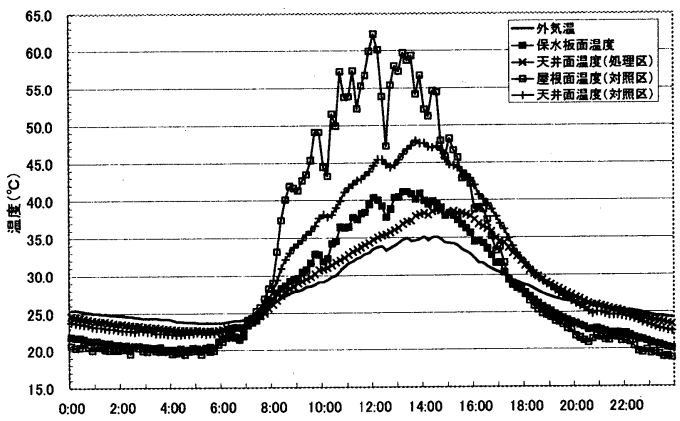

図-13 2005年9月3日の各部温度変化

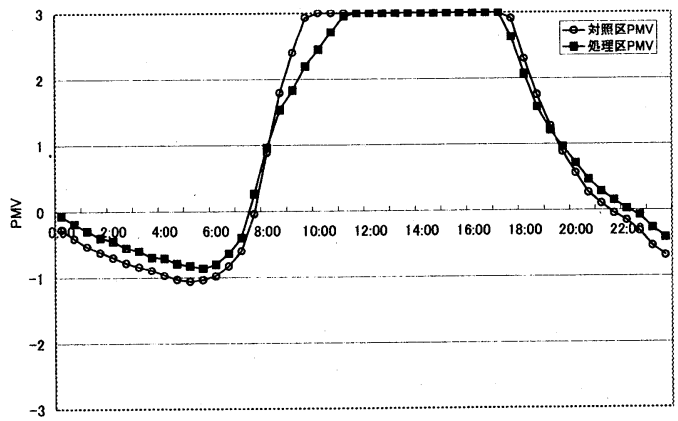

図-14 2005年9月3日のP MV比較

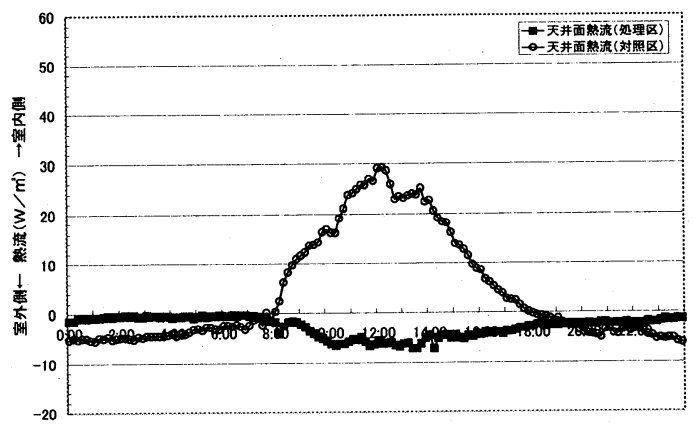

図-15 2005年9月3日の天井面熱流変化 
（5）屋根と壁を被覆・空調時の比較

最も天候が安定していた9月13日の日射量変化を図-16 に示す．9月13日は雲の通過はあるものの，ほぼ晴とな り，日積算日射量は $18.5 \mathrm{MJ} / \mathrm{m}^{2}$ と比較的大きな值となっ た。

温度の変化を図-17に示す. 屋根面で最大 $24.3^{\circ} \mathrm{C}$, 天 井面で最大 $6.2^{\circ} \mathrm{C}$ 差が生じた.

PMVの測定結果は，屋根面のみを被覆した場合と同 様に, 処理区の方が高い值を示した. 平均輻射温度, 室 温も同様に処理区の方が高く, 平均輻射温度と室温との 差は, 処理区の方が小さかった.これらは屋根のみを被 覆した場合とまったく同じ結果である.

天井面熱流の測定結果，対照区では，日中は最大 52.4 $\mathrm{W} / \mathrm{m}^{2}$ の熱が天井面から屋内側に流入していた.しかし ながら処理区のセンサーがこの期間故障しており，この 日の熱流差を解析することはできなかった。

また，空調による1日の電力消費量は図-18のように対 照区で $3.9 \mathrm{kWh}$, 処理区で $2.1 \mathrm{kWh}$ となり, 電力消費量は $46.2 \%$ 減となった. なお，この值は屋根面と壁面をとも に被覆した場合の複合的な効果によるものと考えられ， 壁面を被覆した分の単独効果は分離できないものと考え られる. 壁面のみの被覆効果の検証に関しては今後の課 題としたい.

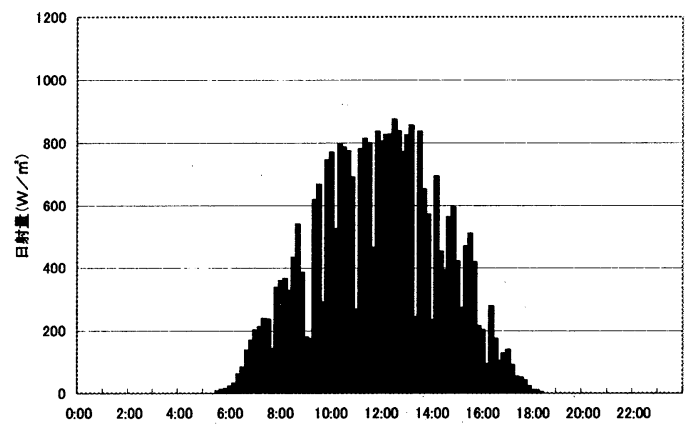

図-16 2005年9月13日の日射量変化

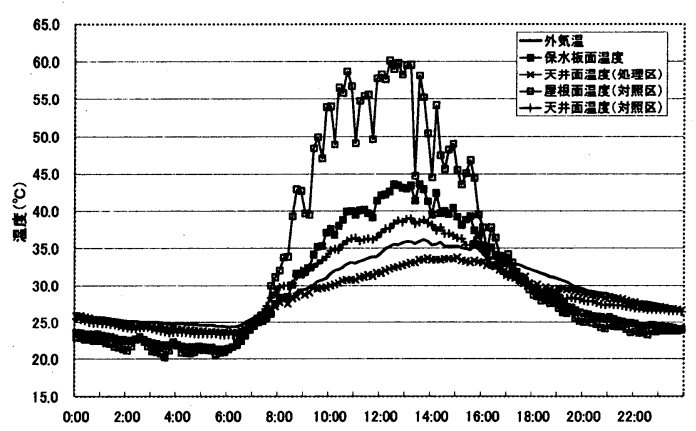

図-17 2005年9月13日の各部温度変化

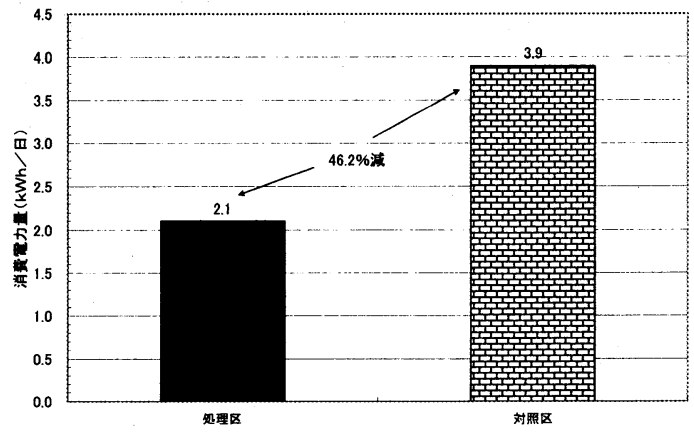

図-18 2005年9月13日の消費電力量比較

\section{4. 総合考察}

以上の実験結果から，保水板を屋根面あるいは壁面に 貼り付けることによって, 明確な熱遮蔽効果が得られる ことが示された. 同一規格のコンテナハウスを用いて， 屋根面をメキシコマンネングサで緑化した場合の実験結 果では, 天井面温度で最大 $7.2 \sim 4.3^{\circ} \mathrm{C}$, 室温で最大 5.1 $\sim 2.2^{\circ} \mathrm{C}$ 差が生じた ${ }^{6)}$. 同一気象条件下での測定では ないため厳密な比較は難しいが, 今回の屋上のみを被覆 した場合の測定結果でも同等以上の温度差が生じている ことから, 屋上緑化に劣らない室内熱環境改善効果が得 られたものと考えられる.

実物建物を用いてエアコンの消費電力量を比較した研 究事例は稀であるが，例えば $\mathrm{R} \mathrm{C}$ 造4階建ての建物屋上 を，ポーラスコンクリート基盤を用いてコウライシバで 緑化した場合で $7.7 \%$ 削減と報告されている7 . また， 工場の折板屋根を芝類で緑化した前後の夏季の電力消費 量比較から，約30\%の削減が行われたという報告などが ある ${ }^{8)}$. 今回は晴天日1日のみの集計であるが，屋根面 のみ設置で $29.3 \%$ 削減, 屋根と壁面のうち 2 面を被覆し た場合で $46.2 \%$ 削減となり，非常に大きな削減効果が得 られた。使用したコンテナハウスの断熱性能はそれほど 高いものではないため， R C造などと比べると効果が大 きく現れるものと考えられるが，十分に実用レベルの削 減効果が得られたものと判断できる.

保水板は軽量で施工性が良好であるため，建築物一般 に広く使える可能性が高く, 建物表面温度を低下させる ことによる顕熱量の低減，また室内冷房負荷の低減によ る排熱量の低減も期待でき，都市のヒートアイランド対 策上も有効であると思われる.

なお，本研究に用いた保水板は試作段階であり，反射 率や熱抵抗值，蒸発特性などが一定していない.今後， 製品化に至つた段階で，それらの基礎的な特性值を明ら かにしていく予定である. 


\section{参考文献}

1) 東京都環境局 : ヒートアイランド対策ガイドライン, pp11-20, 2005.

2) 萩原伸治他 : 保水性建材の蒸発性能に関する実験 : 日本建築 学会学術講演梗概集 D-1,pp.637-638,2005.

3) 三坂育正, 成田健一 : 保水性舗装による都市暑熱環境緩和に 関する研究一その 2 - : 日本建築学会学術講演梗概集 D-1, pp.639-640,2005.

4) Fanger, P.O. : Thermal Comfort. RobertE. Krienger Publishing Company, pp.1-85, 1982 .
5) American Society of Heating Refrigerating and Air Conditioning Engineering : ASHRAEHANDBOOK, pp.242-243, 1995.

6) 山田宏之他 : 薄層基盤屋上緑化がプレハブ建物の屋内熱環境 に与える影響について : 平成 13 年度日本造園学会関西支部 大会研究発表要旨, pp.51-52,2001.

7) 唐沢明彦, 土田 保 : 建築物の熱環境に及ぼす軽量ポーラス コンクリート屋上緑化システムの效果 : 日本緑化工学会誌

27 (1) ,pp.205-208., 2001.

8)関西電力（株） : RELATION, 2003-9,pp.8, 1995.

\title{
RESEARCH ON HEAT INSULATIVE EFFECT OF THE LIGHTWEIGHT AND HIGH WATER HOLDING PROPERTY BOARD
}

\author{
Hiroyuki YAMADA, Akinori TANAKA and Yoshio OKUDA
}

We experimented using the lightweight and high water holding property board which can be installed in the container house roof or the surface of a wall. Change of indoor thermal environment and the mitigation effect of air-conditioning load were analyzed as follows.

1) The temperature of a building roof side was reduced by 24.3-27.6 degrees of celsius.

2) The temperature of a building ceiling side was reduced by 6.2-10.4 degrees of celsius.

3) An indoor mean radiant temperature was reduced by 1.7-6.1 degrees of celsius.

4) The reduction effect of $46.2 \%$ of the amount of air-conditioning electric power was acquired by the case where the roof surface and the 2 nd page in a surface of a wall is covered with the board, and in case where only a roof surface is covered, $29.3 \%$. 